\title{
Exposure to a glyphosate-based herbicide formulation, but not glyphosate alone, has only minor effects on adult rat testis
}

\author{
Johansson, Hanna Katarina Lilith; Schwartz, Camilla Lindgren; Nielsen, Lene Nørby; Boberg, Julie; \\ Vinggaard, Anne Marie; Bahl, Martin lain; Svingen, Terje
}

\section{Published in:}

Reproductive Toxicology

Link to article, DOI:

10.1016/j.reprotox.2018.09.008

Publication date:

2018

Document Version

Peer reviewed version

Link back to DTU Orbit

Citation $(A P A)$ :

Johansson, H. K. L., Schwartz, C. L., Nielsen, L. N., Boberg, J., Vinggaard, A. M., Bahl, M. I., \& Svingen, T. (2018). Exposure to a glyphosate-based herbicide formulation, but not glyphosate alone, has only minor effects on adult rat testis. Reproductive Toxicology, 82, 25-31. https://doi.org/10.1016/j.reprotox.2018.09.008

\section{General rights}

Copyright and moral rights for the publications made accessible in the public portal are retained by the authors and/or other copyright owners and it is a condition of accessing publications that users recognise and abide by the legal requirements associated with these rights.

- Users may download and print one copy of any publication from the public portal for the purpose of private study or research.

- You may not further distribute the material or use it for any profit-making activity or commercial gain

- You may freely distribute the URL identifying the publication in the public portal 


\section{Accepted Manuscript}

Title: Exposure to a glyphosate-based herbicide formulation, but not glyphosate alone, has only minor effects on adult rat testis

Authors: Hanna Katarina Lilith Johansson, Camilla Lindgren

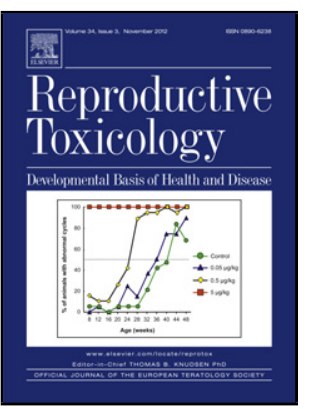
Schwartz, Lene Nørby Nielsen, Julie Boberg, Anne Marie Vinggaard, Martin Iain Bahl, Terje Svingen

PII: S0890-6238(18)30198-9

DOI:

Reference: https://doi.org/10.1016/j.reprotox.2018.09.008

To appear in: $\quad$ Reproductive Toxicology

Received date: $\quad 17-5-2018$

Revised date: 21-9-2018

Accepted date: $\quad$ 26-9-2018

Please cite this article as: Johansson HKL, Schwartz CL, Nielsen LN, Boberg J, Vinggaard AM, Bahl MI, Svingen T, Exposure to a glyphosate-based herbicide formulation, but not glyphosate alone, has only minor effects on adult rat testis, Reproductive Toxicology (2018), https://doi.org/10.1016/j.reprotox.2018.09.008

This is a PDF file of an unedited manuscript that has been accepted for publication. As a service to our customers we are providing this early version of the manuscript. The manuscript will undergo copyediting, typesetting, and review of the resulting proof before it is published in its final form. Please note that during the production process errors may be discovered which could affect the content, and all legal disclaimers that apply to the journal pertain. 


\title{
Exposure to a glyphosate-based herbicide formulation, but not glyphosate alone, has only minor effects on adult rat testis
}

Running Title: Low dose glyphosate exposure has little effect on adult rat testis.

Hanna Katarina Lilith Johansson ${ }^{\mathrm{a}}$, Camilla Lindgren Schwartz ${ }^{\mathrm{a}}$, Lene Nørby Nielsen ${ }^{\mathrm{a}}$, Julie Boberga Anne Marie Vinggaard ${ }^{\mathrm{a}}$, Martin Iain Bahl ${ }^{\mathrm{a}} \&$ Terje Svingen ${ }^{\mathrm{a}, \mathrm{b}}$

a. Division of Diet, Disease Prevention and Toxicology, National Food Institute, Technical University of Denmark, Kgs. Lyngby DK-2800, Denmark

b. Author for correspondence:

Tel: +4593518880

Email: tesv@food.dtu.dk

Highlights

- Exposure to pure glyphosate at 50xADI does not affect testis androgen function in male rats

- Glyphosate-based herbicide formulation has limited effects on adult rat testis, but the effect is likely not driven by glyphosate itself

\begin{abstract}
Glyphosate has been suggested to be an endocrine disrupting chemical capable of disrupting male reproduction. There are conflicting data, however, with studies reporting on effects from exposure to either glyphosate alone or to herbicide formulations, making comparisons difficult. We assessed rat testis histopathology and androgen function following two weeks exposure to either glyphosate at 2.5 and $25 \mathrm{mg} / \mathrm{kg}$ bw/day (5x and 50x Acceptable Daily Intake, ADI, respectively), or equivalent high dose of glyphosate in a herbicide formulation; Glyfonova. We observed no significant effects on testes or testosterone synthesis in rats exposed to glyphosate. Limited effects were observed in rats exposed to Glyfonova, with a small upregulation of the steroidogenic genes Cypllal and Cyp17al. We conclude that glyphosate alone has no effects on adult rat testis at exposure levels up to $25 \mathrm{mg} / \mathrm{kg}$ bw/day. Glyfonova induced only minor effects on steroidogenic gene expression, likely caused by additives other than glyphosate.
\end{abstract}


Key words: glyphosate, testis, androgens, pesticides, testosterone, steroidogenesis, toxicology

\section{INTRODUCTION}

Glyphosate, or $\mathrm{N}$-(phosphonomethyl)glycine, is the active ingredient in numerous herbicide formulations used for weed control. Since its introduction to the market in the 1970s, glyphosate has become the most used herbicide in the world [1], and in the USA alone accounted for more than half of all agricultural herbicides used in 2009 [2, 3]. Glyphosate acts by inhibiting the enzyme 5enolpyruvylshikimate-2-phosphase synthase (EPSP), which is essential for the synthesis of aromatic amino acids in plants. The EPSP enzyme is not present in mammals [4-6] and therefore glyphosate does not cause the same effects in humans. There are, however, concerns that glyphosate may have off-target effects in mammals and potentially cause unwanted health outcomes.

Whether or not glyphosate is harmful to human health, particularly at relevant exposure levels, is much debated. Cancer has been flagged as a concern with regards to glyphosate exposure, albeit this remains controversial and the majority of regulatory bodies consider glyphosate not a likely carcinogen as reviewed in a recent issue paper by the US Environmental Protection Agency [7]. Other proposed health concerns include increased risk of kidney diseases, pregnancy complications, and reproductive dysfunctions, but neither is empirically confirmed $[3,8,9]$. These diseases are diverse in aetiology and manifestations, making it difficult to discern potential common mechanisms of effects. In relation to the reproductive disorders, glyphosate has been suggested to be an endocrine disrupting chemical (EDC).

A limited number of studies have reported disrupted hormone synthesis or signal transduction in various systems and, based on their findings, proposed that glyphosate is an EDC. These include the rat male reproductive organs [10-12] and adrenal gland steroidogenesis [13], as well as cell lines such as rodent Leydig cells $[14,15]$, bovine granulosa cells $[16,17]$, and human embryonic, placental and liver cells $[18,19]$. In many of these studies the tested substance was a commercial formulation of 
glyphosate and thus not the pure active compound. Notably, several of these studies have been strongly criticized and the suggestion that glyphosate is an EDC has been disputed by many [20-23]. It is also important to consider whether additives in herbicide formulations themselves can act as endocrine disrupters, and if they do, it becomes unfeasible to assess potential endocrine effects caused by glyphosate in formulations. Some studies have proposed that herbicide additives can act as EDCs in vitro [24], albeit disrupted hormone synthesis could be an indirect effect of disrupted mitochondrial membrane by the surfactants $[25,26]$, which highlight the importance of assessing mitochondrial function and cytotoxicity when interpreting in vitro data.

It has been suggested that glyphosate exposure during juvenile age can delay puberty, increase testes weight, or decrease circulating testosterone levels [10]. Perinatal exposure reportedly causes elevated circulating testosterone levels and changes to sexual behaviour in adulthood [11]. In both of these studies, exposure was to the herbicide formulation Roundup Transorb and not glyphosate alone, which precludes the possibility of evaluating if it is glyphosate or other constituents from the formulation that cause the effects. Another study reported no significant effect on testosterone levels, albeit with a decreasing trend at higher doses following expose of adult male rats to pure glyphosate [12]. Interestingly, Dai and co-workers observed reduced sperm count and a decrease of the weight of seminal vesicle gland at the high doses, but without any obvious histopathological effects on the testes. There are few studies reporting on effects on sperm parameters, but also here the results are contradictory. A recent meta-analysis concluded that glyphosate exposure lowers sperm concentration in rodents and thus has a detrimental effect on male reproduction [27].

Herein, we have examined the effect of glyphosate exposure as both active compound and commercial formulation (Glyfonova ${ }^{\circledR} 450$ Plus) on testis androgen function in adult rats. The animal study was primarily designed to investigate the effect of glyphosate on the intestinal microbiota [28], but with an exposure regimen suitable to also investigate effects on male reproductive function, including parameters such as testosterone synthesis, testicular histology and molecular profiling. 


\section{MATERIALS AND METHODS}

\subsection{Chemicals}

The chemicals used were: glyphosate (N-(Phosphonomethyl)glycine (Sigma-Aldrich 1071-83-6; purity $\geq 96 \%$ ) and Glyfonova ${ }^{\circledR} 450$ Plus (gift in kind from FMC Corporation, previously Cheminova A/S) containing $450 \mathrm{~g} / \mathrm{L}$ glyphosate acid equivalent. The components of the surfactant blend in the Glyfonova formulation contains: poly(oxy-1,2-ethandiyl), alfa-phosphono-omega-butoxy-, isopropylamine salt: $\max 4 \%$ (CAS no. 431040-31-2), 2-(2-(2-butoxyethoxy)ethoxy)ethanol: max 1\% (CAS no. 143-22-6), and ethanol and ethoxylated alcohols (C8-C10): $\max 1 \%$ (CAS no. 71060-57-6). The complete data sheet (in Danish) is available at: http://www.fmcagro.dk/download/produkter/glyfonova_450_plus/Glyfonova450Plus_SDS_DK.pdf

\subsection{Animals}

Animal experiments were carried out in accordance with the Danish Animal Experiments Inspectorate, and the study had ethical approval (authorization no. 2012-15-0201-00553 C2). A detailed description of the study design has previously been published [28]. Briefly, eighty 4-week old male SpragueDawley rats (Taconic Biosciences, Lille Skensved, Denmark) were randomly caged in pairs and acclimatized for 7 days. Cages were subsequently distributed into four exposure groups based on animal weight, but following exposure only one animal per cage was used for analyses. Animals were exposed to water (CTR), $2.5 \mathrm{mg} / \mathrm{kg} /$ day glyphosate (GLY5), $25 \mathrm{mg} / \mathrm{kg} /$ day glyphosate (GLY50), or 25 $\mathrm{mg} / \mathrm{kg} /$ day Glyfonova ${ }^{\circledR} 450$ Plus (NOVA) by oral gavage. Group names reflect that the low dose is 5xADI, and the high dose is 50xADI, relative to the European ADI of $0.5 \mathrm{mg} / \mathrm{kg}$ bw/day [29]. After two weeks of exposure, animals were decapitated under $\mathrm{CO}_{2} / \mathrm{O}_{2}$ sedation and the testes collected. From each of 10 males per dose group, one testis, selected at random, was snap frozen in liquid nitrogen and the other fixed in $10 \%$ formalin. 


\subsection{Heptane extraction of hormones and testosterone assay}

One half of each testis was used for hormone extraction ( $n=10$ /group). Testes were cut into two equally sized pieces and the testis cap separated from the remaining tissue using a spatula. The inner tissue (seminiferous tubules and interstitial cells) was transferred immediately to a pre-weighed glass vial containing $0.5 \mathrm{~mL}$ sterile water and re-weighed to determine total tissue weight per sample. Subsequently, $2.5 \mathrm{~mL}$ heptane was added and the sample homogenized by manual disruption, then placed on dry ice-acetone mix until the water portion was frozen solid. The heptane fraction was transferred to a fresh glass vial and the process repeated to yield a second $2.5 \mathrm{~mL}$ heptane fraction that was pooled together with the first fraction. Samples were then dried under gaseous nitrogen. Before hormone analyses, the dried samples were dissolved in EIA buffer (Cayman chemicals, USA) at $4{ }^{\circ} \mathrm{C}$ overnight, then vortexed for $30 \mathrm{~s}$ and placed in a $42{ }^{\circ} \mathrm{C}$ water bath for $10 \mathrm{~min}$. Intra-testicular testosterone assays were performed using the Testosterone ELISA kit (Cayman chemicals, USA) according to the manufacturer's instructions. Reads were obtained using 96-well plates and absorbance read at $405 \mathrm{~nm}$ using a microplate reader (2300 EnSpire ${ }^{\mathrm{TM}}$, PerkinElmer). Each sample was assayed in duplicates and result means presented as pg testosterone / g testis (converted to ng/g tissue in Fig. 1).

\subsection{Histology, Immunohistochemistry and immunofluorescence}

Testes were fixed in $10 \%$ formalin, processed for paraffin embedding and sectioned at $5 \mu \mathrm{m}$ for histological assessments. Hematoxylin \& Eosin (H\&E) staining was performed following standard protocols. Immunohistochemistry (IHC) with peroxidase was carried out on sections of formalin-fixed testes. Sections were dewaxed in petroleum for $2 \times 10 \mathrm{~min}$, then rehydrated by immersion for $5 \mathrm{~min}$ in each 99\%, 96\%, 70\% ethanol and finally running tap water for 5 min. Antigen retrieval was carried out in $0.01 \mathrm{M}$ citrate buffer $(\mathrm{pH}$ 6) in a microwave for $2 \times 5 \mathrm{~min}$, and then allowed to cool at room temperature. Samples were washed in PBS and blocked with $1 \%$ bovine serum albumin (BSA) for 30 min, then incubated overnight at $4{ }^{\circ} \mathrm{C}$ with primary antibody (in blocking solution). The following day, samples were washed $3 \times 5$ min in PBS, blocked with $3 \% \mathrm{H}_{2} \mathrm{O}_{2}$ for $10 \mathrm{~min}$ and again washed $3 \times 5$ min in PBS. Samples were incubated with EnVision+ System (Dako) for 30 min, washed 3 x 5 min, then with Liquid DAB+ System (Dako) for 15 min and washed. To visualize all cell nuclei, sections 
were counterstained with Meyers' hematoxylin for $1 \mathrm{~min}$. Following washing and rehydration, samples were mounted with Eukitt. The primary antibody used was against the Androgen receptor (AR; 1:400, Santa Cruz, cat.no. AR(N-20)SC-816).

Immunofluorescence (IF) was carried out essentially as previously described [30]. Briefly, $5 \mu \mathrm{m}$ sections $(n=4 /$ group $)$ were dewaxed in petroleum, washed in ethanol and dehydrated. Antigen retrieval was by heat treatment in a microwave for 15 min immersed in Tris-EDTA buffer ( $\mathrm{pH}$ 9), then cooled at room temp before washed in PBS and blocked in 5\% bovine serum albumin (BSA) for $1 \mathrm{~h}$. Samples were incubated with primary antibodies overnight at $4^{\circ} \mathrm{C}$. The next day, slides were brought to room temperature and incubated with secondary antibodies for $1 \mathrm{~h}$ in the dark. Samples were counterstained with 4,6-diamidino-2-phenylindole (DAPI; Sigma). Primary antibodies were: goat antiHSD3ß (1:200; Santa Cruz, cat.no. sc30820), rabbit anti-DDX4 (1:200; Abcam, cat.no. 13840), goat anti-CYP11A1 (1:200; Santa Cruz, cat.no. sc18043), and rabbit anti-STAR (1:1000; Affinity BioReagents, cat.no. PA1-560). Secondary antibodies were used at 1:500 dilutions and were: donkey anti-goat AlexaFluor-488 and donkey anti-rabbit AlexaFluor-568 (Molecular Probes).

\subsection{RNA extraction, cDNA synthesis and quantitative RT-PCR}

Protocols and selection of reference genes were essentially as described previously [31]. Briefly, total RNA (RNeasy Mini Kit, Qiagen) was extracted from a 100 mg cross-sectional piece from each testis ( $\mathrm{n}=10$ /group), of which 500 ng RNA was used for each cDNA synthesis (Omniscript; Qiagen). TaqMan Gene Expression Assays (Life Technologies) were: Ar (Rn00560747), Ddx4 (Rn01489814), Cyp11a1 [32], Cyp17al [32], Insl3 (Rn00586632), Pcna (Rn01514538), Star [32], and Hsd3b1 (Rn017747410). RT-qPCR assays were run on a QuantStudio 7 Flex Real-Time PCR System (Applied Biosystems) in a 384-well format using $3 \mu \mathrm{l}$ diluted (1:20) cDNA as template in each $20 \mu 1$ reaction. Relative transcript abundance was calculated by the comparative Ct-method with the geometric mean of the reference genes Sdha (Rn00590475) and Rpl13a (Rn00821946).

\subsection{Apoptosis}


One section per testis ( $n=5$ /group) was stained with terminal deoxynucleotidyl transferase dUTP nick end labelling (TUNEL, Apoptag ${ }^{\circledR}$ Peroxidase In Situ Apoptosis Detection Kit, EMD Millipore Corporation) according to manufacturer's instructions with one exception; pre-dilution (1:80) of the TdT enzyme in MilliQ water before dilution with Reactionbuffer. Color was developed for 15min using DAB+ substrate (DAKO, Glostrup, Denmark). Lastly, the nuclei were stained using Mayer Hematoxylin (Ampliqon, Odense, Denmark) prior to mounting using Eukitt (Sigma-Aldrich, Germany). All positively stained cells within the seminiferous tubules on a cross-section were counted by an observer blinded to treatment groups. Cells that were clearly stained as a result of cell division rather than apoptosis were excluded, as were stained cells at the outer border of the tissue sections, as they were considered technical artefacts. The relative area of seminiferous tubuli were calculated as essentially as described previously [33]: First, relative percentage of seminiferous epithelium to whole testis was calculated using a 15 point-grid count on three separate fields of view from each sample. Second, whole testis section areas were calculated in Adobe Photoshop CC 2017 using the measurement tool. Third, apoptotic cells were defined relative to percentage seminiferous epithelium to whole section. Data and statistical analyses are presented as number of apoptotic cells per seminiferous tubuli area.

\subsection{Statistical analysis}

Data was tested for normal distribution and homogeneity of variance (logarithmic transformation was applied if required). ANOVA with Dunnett's post-test was applied and p-values below 0.05 were considered statistically significant. Statistical software GraphPad Prism 5 (GraphPad Software, San Diego California USA) was used for analysis. 


\section{RESULTS}

\subsection{Testosterone levels}

To assess potential effects on testis androgen function in exposed rats, we measured intra-testicular testosterone levels by ELISA. We observed no significant changes in any of the three exposure groups compared to control animals (Fig. 1).

\subsection{Quantitative gene and protein expression analysis}

We next analysed the expression of key marker genes in the testes to look for molecular changes indicative of disrupted testis function or cellularity. In the testis from animals exposed to either 5xADI (GLY5) or 50xADI (GLY50), we observed no significant differences in gene expression compared to controls (Fig. 2). In the NOVA exposed testes, however, there was a small but significant upregulation in the P450 enzyme encoding genes Cypllal $(\mathrm{p}=0.02)$ and Cyp17al $(\mathrm{p}=0.03)$. We found no significant differences between treatment groups and controls in the other Leydig cell-specific genes Insl3, Hsd3b1 and Star, the somatic marker Ar or germ cell marker Ddx4. We therefore argue that the observed higher transcript levels for Cypl lal and Cyp17al were due to upregulated gene transcription and not caused by altered cellularity within the testis, further corroborated by no significant differences to transcript levels of additional markers Sox9, Acta2 and Gata1 (data not shown).

\subsection{Testis histopathology and qualitative protein expression analysis}

The testes were examined histologically and by immunohistochemistry to assess in more detail if architecture and cellular integrity was maintained after exposure to glyphosate. First, serial sections were immunostained with antibodies against cell-specific markers. The Leydig cell-specific steroidogenesis factors CYP11A1 and STAR were both expressed at comparative levels across all groups (Fig. 3A). Similarly, relative expression levels and distribution of the steroidogenic enzyme HSD3B1 and the germ cell-specific factor DDX4 were comparative between all exposure groups and control animals (Fig. 3B). 
We next analysed testes sections stained with $\mathrm{H} \& \mathrm{E}$ and immunostained with an antibody against AR (Fig. 4). We observed no adverse histopathology in any of the exposed groups compared with controls. Seminiferous tubules were intact and displayed active spermatogenesis, with comparable spermatogenic cycling between examined specimens (qualitative assessment). Neither was any differences between exposed and control animals observed with regard to missing germ cell layers or multinucleated germ cells. The interstitial space was comparable between all examined samples. Staining intensity (H\&E) was similar across specimens. It is well described that a sensitive marker of decreased testosterone levels is the degeneration of pachytene spermatocytes and round spermatids in stage VII-VIII of the spermatogenic cycle [34]. Thus, we also examined five samples from each group for potential changes in apoptotic activity by TUNEL assay (Fig. 5). A limited number of TUNELpositive cells were seen, with no differences in apoptotic rate in any of the exposure groups compared to controls.

\section{DISCUSSION}

The question whether glyphosate exposure poses any risks to human health remains unresolved. Glyphosate has been suggested to have endocrine disrupting properties and negatively impact on male reproduction. The literature is contradictory, however, and recent regulatory reviews conclude that glyphosate is likely not an EDC $[22,23,29]$. In this study, we wanted to investigate the effect of glyphosate and the commercial herbicide formulation, Glyfonova ${ }^{\circledR} 450$ on intra-testicular testosterone levels, testicular gene and protein expression, testicular histopathology and apoptosis in the testes. Glyphosate at 5xADI and 50xADI did not show significant effects on any of the included endpoints. The glyphosate-based formulation Glyfonova induced a smaller change to two key steroidogenic genes Cyp1 1a1 and Cyp17al at 50xADI, but no other measured endpoint were significantly affected.

\subsection{Testosterone levels}

Effects on testosterone levels following glyphosate exposure have been reported [10, 11], albeit disputed [20]. Notably also, the studies were conducted with glyphosate-based herbicide formulations 
and not glyphosate alone [10, 11]. Furthermore, in both in vivo and in vitro studies using glyphosate alone, no effects on testosterone levels were observed $[12,35]$. In the present study, there was neither an effect on testosterone levels following exposure to glyphosate alone nor the formulation Glyfonova $^{\circledR} 450$. Contrary to previous studies, however, we measured intra-testicular testosterone levels and not serum hormone levels [10-12]. This usually gives rise to similar outcomes with lower variations, but we cannot exclude the possibility that this could contribute to the difference seen for the herbicide formulations. An additional parameter potentially explaining some differences in observed effects between our and previous studies is exposure doses. We limited exposure to 2.5 and $25 \mathrm{mg} / \mathrm{kg}$ bw/day, whereas for instance Romano et al (2010) applied doses of 5,50 and $250 \mathrm{mg} / \mathrm{kg}$ bw/day of a glyphosate-based herbicide formulation, and observed lower serum testosterone at lower doses, but most pronounced at the highest dose. Yet others have exposed rats to various doses of glyphosate $(5,50$, and $500 \mathrm{mg} / \mathrm{kg})$, without inducing significant changes to testosterone levels [12]. This suggests that the reduction in testosterone levels was caused by constituents of glyphosate-based herbicide formulations other than the active ingredient glyphosate.

\subsection{Molecular markers}

Marker gene expression in the glyphosate-exposed testes was unchanged relative to control testes, but the two Leydig cell-specific steroidogenic genes Cypllal and Cyp17al were upregulated in the NOVA (Glyfonova ${ }^{\circledR} 450$ Plus) exposed group. Although testosterone levels were unchanged in the same animals, this indicates some degree of disruption to testis function that could potentially be exasperated at higher doses. However, considering that real-life exposure levels to glyphosate are far below what we have tested at 50xADI - for instance estimated to a maximum systemic dose of 0.004 $\mathrm{mg} / \mathrm{kg}$ from urine measurements in farm families [36] - any implications of such effects may be questioned. A study involving eight-day exposure to a glyphosate-based herbicide formulation in adult rats showed upregulation of Cyp19al (aromatase), another key steroidogenic gene [37]. Both that study and ours thus find altered gene expression following exposure to a herbicide formulation, and not glyphosate alone. Few studies have explored the relationship between Leydig cell gene expression 
and glyphosate exposure. In granulosa cells of bovine ovaries, however, exposure to glyphosate alone had no effect on either Cyp19al or Cyp11a1 [17].

Rather than acting directly on the testes, changes to steroidogenesis and testosterone levels could occur indirectly by disrupting the hypothalamic-pituitary-gonadal axis (HPG-axis). A rat study using a commercial glyphosate-based formulation observed both a downregulation of Star expression in the adrenal and lower testosterone levels in the blood [13]. Interestingly, co-exposure to adrenocorticotropic hormone $(\mathrm{ACTH})$ rescued Star expression, indicating an inhibitory effect on the HPG-axis. This potential mechanism of action is further supported in a separate study showing upregulation of lutenizing hormone $(\mathrm{LH})$ at both the transcriptional and protein level in the pituitary gland, as well as increased LH serum levels after exposure to a glyphosate-based herbicide formulation. Finally, STAR expression in mouse MA-10 Leydig tumor cells is also affected following exposure to a glyphosate-based herbicide formulation, but not glyphosate alone [14]. Hence, it is possible that some of these reported effects are caused by disrupted HPG-axis signaling and not by direct effects on target tissues such as the testes. It appears that most effects are observed following exposure to glyphosate-based herbicide formulations. This suggests that the active compound glyphosate may not contribute to previously reported endocrine disrupting effects, but rather other constituents in the commercial formulated products. This is further in agreement with conclusions from the most recent expert opinion review on glyphosate commissioned by the European Food Safety Authority [23], which conclude that there is no evidence of endocrine mode of action of glyphosate.

\section{FUNDING}

This work was partially funded by a grant from the Danish Environmental Protection agency (project number 667-00208).

\section{ACKNOWLEDGMENTS}


We thank Birgitte Plesning, Heidi Letting and Mette Voigt Jessen for their skilled laboratory assistance.

\section{AUTHORS' DECLARATION}

The authors declare no conflicts of interest. The major sponsors of this work, the Danish EPA, had no involvements in study design, data collection and interpretation, in the writing of the report, nor the decision to publish.

\section{REFERENCES}

1. A.D. Baylis, Why glyphosate is a global herbicide: strengths, weaknesses and prospects. Pest Manag Sci. 56 (2000) 299-308. DOI: 10.1002/(SICI)15264998(200004)56:4<299::AID-PS144>3.0.CO;2-K.

2. R.H. Coupe and P.D. Capel, Trends in pesticide use on soybeans, corn and cotton since the introduction of major genetically modified crops in the United States. Pest Manag Sci. 72 (2016) 1013-1022. DOI: 10.1002/ps.4082.

3. J.P. Myers, M.N. Antoniou, B. Blumberg, L. Carroll, T. Colborn, L.G. Everett, M. Hansen, P.J. Landrigan, B.P. Lanphear, R. Mesnage, et al., Concerns over use of glyphosate-based herbicides and risks associated with exposures: a consensus statement. Environ Health. 15 (2016) 19. DOI: 10.1186/s12940-016-0117-0.

4. E. Schönbrunn, S. Eschenburg, W.A. Shuttleworth, J.V. Schloss, N. Amrhein, J.N. Evans, and W. Kabsch, Interaction of the herbicide glyphosate with its target enzyme 5-enolpyruvylshikimate 3-phosphate synthase in atomic detail. Proc Natl Acad Sci U S A. 98 (2001) 1376-1380. DOI: 10.1073/pnas.98.4.1376.

5. J.L. Rubin, C.G. Gaines, and R.A. Jensen, Glyphosate inhibition of 5enolpyruvylshikimate 3-phosphate synthase from suspension-cultured cells of nicotiana silvestris. Plant Physiol. 75 (1984) 839-845. DOI: 10.1104/pp.75.3.839.

6. H. Holländer-Czytko and N. Amrhein, 5-enolpyruvylshikimate 3-phosphate synthase, the target enzyme of the herbicide glyphosate, is synthesized as a precursor in a higher plant. Plant Physiol. 83 (1987) 229-231. DOI: 10.1104/pp.83.2.229.

7. US-EPA, Revised glyphosate issue paper: Evaluation of carcinogenic potential. EPA's office of pesticide programs, (2017) https://www.regulations.gov/document?D=EPAHQ-OPP-2009-0361-0073.

8. A.H.C. Van Bruggen, M.M. He, K. Shin, V. Mai, K.C. Jeong, M.R. Finckh, and J.G.J. Morris, Environmental and health effects of the herbicide glyphosate. Sci Total Environ. 616-617 (2018) 255-268. DOI: 10.1016/j.scitotenv.2017.10.309.

9. S.H. Bai and S.M. Ogbourne, Glyphosate: environmental contamination, toxicity and potential risks to human health via food contamination. Environ Sci Pollut Res Int. 23 (2016) 18988-19001. DOI: 10.1007/s11356-016-7425-3.

10. R.M. Romano, M.A. Romano, M.M. Bernardi, P.V. Furtado, and C.A. Oliveira, Prepubertal exposure to commercial formulation of the herbicide glyphosate alters 
testosterone levels and testicular morphology. Arch Toxicol. 84 (2010) 309-317. DOI: 10.1007/s00204-009-0494-z.

11. M.A. Romano, R.M. Romano, L.D. Santos, P. Wisniewski, D.A. Campos, P.B. de Souza, P. Viau, M.M. Bernardi, M.T. Nunes, and C.A. de Oliveira, Glyphosate impairs male offspring reproductive development by disrupting gonadotropin expression. Arch Toxicol. 86 (2012) 663-673. DOI: 10.1007/s00204-011-0788-9.

12. P. Dai, P. Hu, J. Tang, Y. Li, and C. Li, Effect of glyphosate on reproductive organs in male rat. Acta Histochem. 118 (2016) 519-526. DOI: 10.1016/j.acthis.2016.05.009.

13. A. Pandey and M. Rudraiah, Analysis of endocrine disruption effect of Roundup ${ }^{\circledR}$ in adrenal gland of male rats. Toxicol Rep. 2 (2015) 1075-1085. DOI: 10.1016/j.toxrep.2015.07.021.

14. L.P. Walsh, C. McCormick, C. Martin, and D.M. Stocco, Roundup inhibits steroidogenesis by disrupting steroidogenic acute regulatory (StAR) protein expression. Environ Health Perspect. 108 (2000) 769-776.

15. E. Clair, R. Mesnage, C. Travert, and G.É. Séralini, A glyphosate-based herbicide induces necrosis and apoptosis in mature rat testicular cells in vitro, and testosterone decrease at lower levels. Toxicol In Vitro. 26 (2012) 269-279. DOI: 10.1016/j.tiv.2011.12.009.

16. M.C. Perego, F. Caloni, C. Cortinovis, L.F. Schutz, M. Albonico, D. Tsuzukibashi, and L.J. Spicer, Influence of a Roundup formulation on glyphosate effects on steroidogenesis and proliferation of bovine granulosa cells in vitro. Chemosphere. 188 (2017) 274-279. DOI: 10.1016/j.chemosphere.2017.09.007.

17. M.C. Perego, L.F. Schutz, F. Caloni, C. Cortinovis, M. Albonico, and L.J. Spicer, Evidence for direct effects of glyphosate on ovarian function: glyphosate influences steroidogenesis and proliferation of bovine granulosa but not theca cells in vitro. $\mathrm{J}$ Appl Toxicol. 37 (2017) 692-698. DOI: 10.1002/jat.3417.

18. N. Benachour, H. Sipahutar, S. Moslemi, C. Gasnier, C. Travert, and G.E. Séralini, Time- and dose-dependent effects of roundup on human embryonic and placental cells. Arch Environ Contam Toxicol. 53 (2007) 126-133. DOI: 10.1007/s00244-0060154-8.

19. C. Gasnier, C. Dumont, N. Benachour, E. Clair, M.C. Chagnon, and G.E. Séralini, Glyphosate-based herbicides are toxic and endocrine disruptors in human cell lines. Toxicology. 262 (2009) 184-191. DOI: 10.1016/j.tox.2009.06.006.

20. J.M. DeSesso and A.L. Williams, Comment on "Glyphosate impairs male offspring reproductive development by disrupting gonadotropin expression" by Romano et al. 2012. Arch Toxicol. 86 (2012) 1791-1793. DOI: 10.1007/s00204-012-0894-3.

21. A.L. Williams, R.E. Watson, and J.M. DeSesso, Developmental and reproductive outcomes in humans and animals after glyphosate exposure: a critical analysis. $\mathrm{J}$ Toxicol Environ Health B Crit Rev. 15 (2012) 39-96. DOI: 10.1080/10937404.2012.632361.

22. US-EPA, Endocrine disruptor screening program tier 1 screening determinations and associated data evaluation records.

(2015) https://www.regulations.gov/contentStreamer?documentId=EPA-HQ-OPP-20090361-0047\&disposition=attachment\&contentType $=$ pdf.

23. EFSA Peer review of the pesticide risk assessment of the potential endocrine disrupting properties of glyphosate EFSA J, 2017. 15, e04979.

24. N. Defarge, J. Spiroux de Vendômois, and G.E. Séralini, Toxicity of formulants and heavy metals in glyphosate-based herbicides and other pesticides. Toxicol Rep. 5 (2017) 156-163. DOI: 10.1016/j.toxrep.2017.12.025. 
25. S.L. Levine, Z. Han, J. Liu, D.R. Farmer, and V. Papadopoulos, Disrupting mitochondrial function with surfactants inhibits MA-10 Leydig cell steroidogenesis. Cell Biol Toxicol. 23 (2007) 385-400. DOI: 10.1007/s10565-007-9001-6.

26. R. Judson, K. Houck, M. Martin, A.M. Richard, T.B. Knudsen, I. Shah, S. Little, J. Wambaugh, R. Woodrow Setzer, P. Kothiya, et al., Editor's Highlight: Analysis of the Effects of Cell Stress and Cytotoxicity on In Vitro Assay Activity Across a Diverse Chemical and Assay Space. Toxicol Sci. 152 (2016) 323-339. DOI: 10.1093/toxsci/kfw092.

27. W. Cai, Y. Ji, X. Song, H. Guo, L. Han, F. Zhang, X. Liu, H. Zhang, B. Zhu, and M. $\mathrm{Xu}$, Effects of glyphosate exposure on sperm concentration in rodents: A systematic review and meta-analysis. Environ Toxicol Pharmacol. 55 (2017) 148-155. DOI: 10.1016/j.etap.2017.07.015.

28. L.N. Nielsen, H.M. Roager, M.E. Casas, H.L. Frandsen, U. Gosewinkel, K. Bester, T.R. Licht, N.B. Hendriksen, and M.I. Bahl, Glyphosate has limited short-term effects on commensal bacterial community composition in the gut environment due to sufficient aromatic amino acid levels. Environ Pollut. 233 (2018) 364-376. DOI: 10.1016/j.envpol.2017.10.016.

29. EFSA, Conclusion on the peer review of the pesticide risk assessment of the active substance glyphosate. EFSA J. 13 (2015) 1-107. DOI: 10.2903/j.efsa.2015.4302.

30. T. Svingen, M. François, D. Wilhelm, and P. Koopman, Three-dimensional imaging of Proxl-EGFP transgenic mouse gonads reveals divergent modes of lymphangiogenesis in the testis and ovary. PLoS One. 7 (2012) e52620. DOI: 10.1371/journal.pone.0052620.

31. T. Svingen, H. Letting, N. Hadrup, U. Hass, and A.M. Vinggaard, Selection of reference genes for quantitative RT-PCR (RT-qPCR) analysis of rat tissues under physiological and toxicological conditions. PeerJ. 3 (2015) e855. DOI: 10.7717/peerj.855.

32. P. Laier, S.B. Metzdorff, J. Borch, M.L. Hagen, U. Hass, S. Christiansen, M. Axelstad, T. Kledal, M. Dalgaard, C. McKinnell, et al., Mechanisms of action underlying the antiandrogenic effects of the fungicide prochloraz. Toxicol Appl Pharmacol. 213 (2006) 160-171. DOI: 10.1016/j.taap.2005.10.013.

33. J. Boberg, H.K. Johansson, N. Hadrup, K. Dreisig, L. Berthelsen, K. Almstrup, A.M. Vinggaard, and U. Hass, Perinatal exposure to mixtures of anti-androgenic chemicals causes proliferative lesions in rat prostate. Prostate. 75 (2015) 126-140. DOI: $10.1002 /$ pros. 22897 .

34. OECD Series on testing and assessment: Testing for endocrine disrupters. No. 106. Guidance document for histologic evaluation of endocrine and reproductive tests in rodents. Part 2. Male Reproductive system. 2009. Available from: http://www.oecd.org/chemicalsafety/testing/seriesontestingandassessmenttestingforen docrinedisrupters.htm.

35. A.L. Forgacs, Q. Ding, R.G. Jaremba, I.T. Huhtaniemi, N.A. Rahman, and T.R. Zacharewski, BLTK1 murine Leydig cells: a novel steroidogenic model for evaluating the effects of reproductive and developmental toxicants. Toxicol Sci. 127 (2012) 391402. DOI: $10.1093 /$ toxsci/kfs 121.

36. J.F. Acquavella, B.H. Alexander, J.S. Mandel, C. Gustin, B. Baker, P. Chapman, and M. Bleeke, Glyphosate biomonitoring for farmers and their families: results from the Farm Family Exposure Study. Environ Health Perspect. 112 (2004) 321-326. DOI: 10.1289/ehp.6667.

37. E. Cassault-Meyer, S. Gress, G.É. Séralini, and I. Galeraud-Denis, An acute exposure to glyphosate-based herbicide alters aromatase levels in testis and sperm nuclear 
quality. Environ Toxicol Pharmacol. 38 (2014) 131-140. DOI: 10.1016/j.etap.2014.05.007. 


\section{FIGURE LEGENDS}

Figure 1: Intra-testicular testosterone levels were not significantly altered following exposure to glyphosate alone or in a pesticide formulation. Young adult male rats were exposed for two weeks to $2.5 \mathrm{mg} / \mathrm{kg}$ bw/day (GLY5), $25 \mathrm{mg} / \mathrm{kg}$ bw/day (GLY50) glyphosate, or a $25 \mathrm{mg} / \mathrm{kg}$ bw/day equivalent glyphosate dose in a pesticide formulation (NOVA). Intratesticular testosterone levels were measured from one testis per animal ( $\mathrm{N}=10$ each group) following heptane extraction.

Figure 2: Expression of genes involved in steroidogenesis was slightly upregulated in testis following exposure to a glyphosate-containing pesticide formulation, but not glyphosate alone. RT-qPCR analysis revealed that expression of $A r$, the germ cell marker $D d x 4$, and the Leydig cell markers Insl3 and Hsd3bl were unchanged in exposed rats, whereas the Leydig cell-specific steroidogenic genes Cypllal and Cyp17al were significantly upregulated in rats following two weeks of exposure to $25 \mathrm{mg} / \mathrm{kg} \mathrm{bw} / \mathrm{day}$ glyphosate in a pesticide formulation (NOVA). No significant changes were observed in testis from rats exposed to glyphosate alone. $\mathrm{N}=10$ each group; ${ }^{*} \mathrm{p}<0.05$.

Figure 3: Assessment of protein expression in testes from glyphosate-exposed rats revealed no obvious alterations. Cross-sections of formalin-fixed testes were immunostained with antibodies against A) two Leydig-cell markers and steroidogenesis factors CYP11A1 (green) and STAR (red), and B) Leydig cell marker HSD3ß (green) and germ cell marker DDX4 (red). Samples were counterstained with DAPI (blue). No obvious qualitative changes to expression or tissue histology were observed in any of the samples. $\mathrm{N}=$ 5 each group; scale bar $=50 \mu \mathrm{m}$.

Figure 4: No histological alterations in testes from glyphosate-exposed rats. Crosssections of formalin-fixes testes were stained with hematoxylin \& eosin (H\&E), or immunostained with an antibody against AR (brown) and counterstained with hematoxylin (blue). AR showed strong expression in Leydig, Sertoli, and majority of peritubular cells, with no obvious changes in AR expression or tissue histology in glyphosate-exposed testes. $\mathrm{N}$ $=5$; scale bar $=100 \mu \mathrm{m}$. 
Figure 5: The rate of apoptosis was comparative between glyphosate-exposed and control testes. A) Cross-section of formalin-fixed testes were stained with TUNEL (brown) and counterstained with hematoxylin (blue). TUNEL-positive cells within the seminiferous tubules that were not obviously in cell division were counted across the entire section. B) The number of apoptotic cells were comparable between control testes and all exposure groups. $\mathrm{N}$ $=5$ each group; scale bar $=50 \mu \mathrm{m}$. 


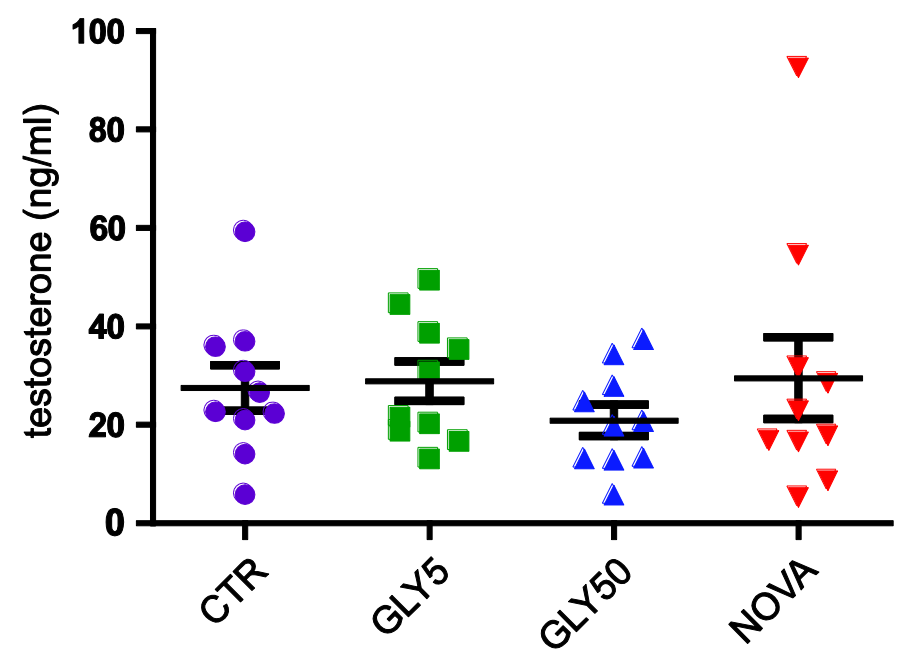



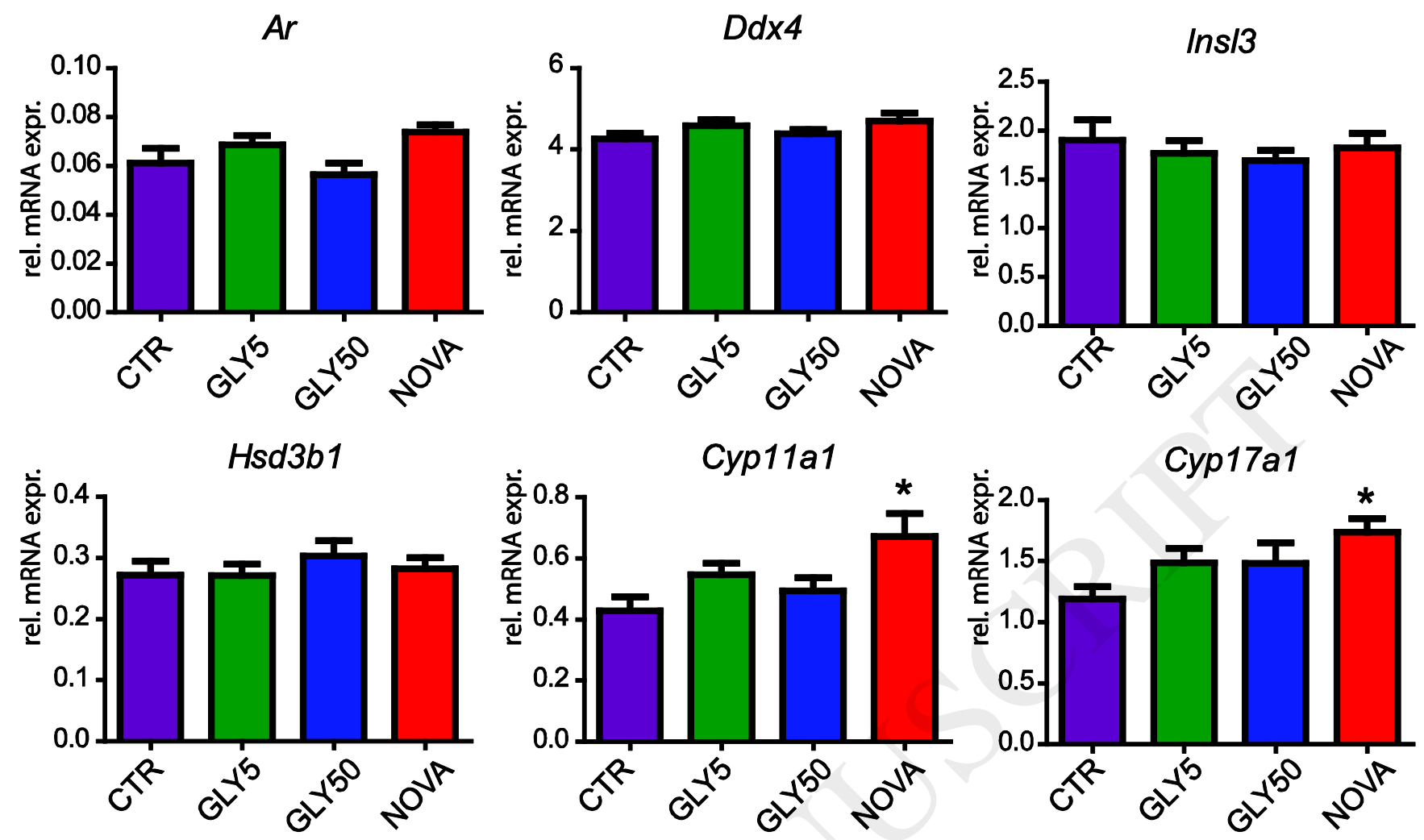


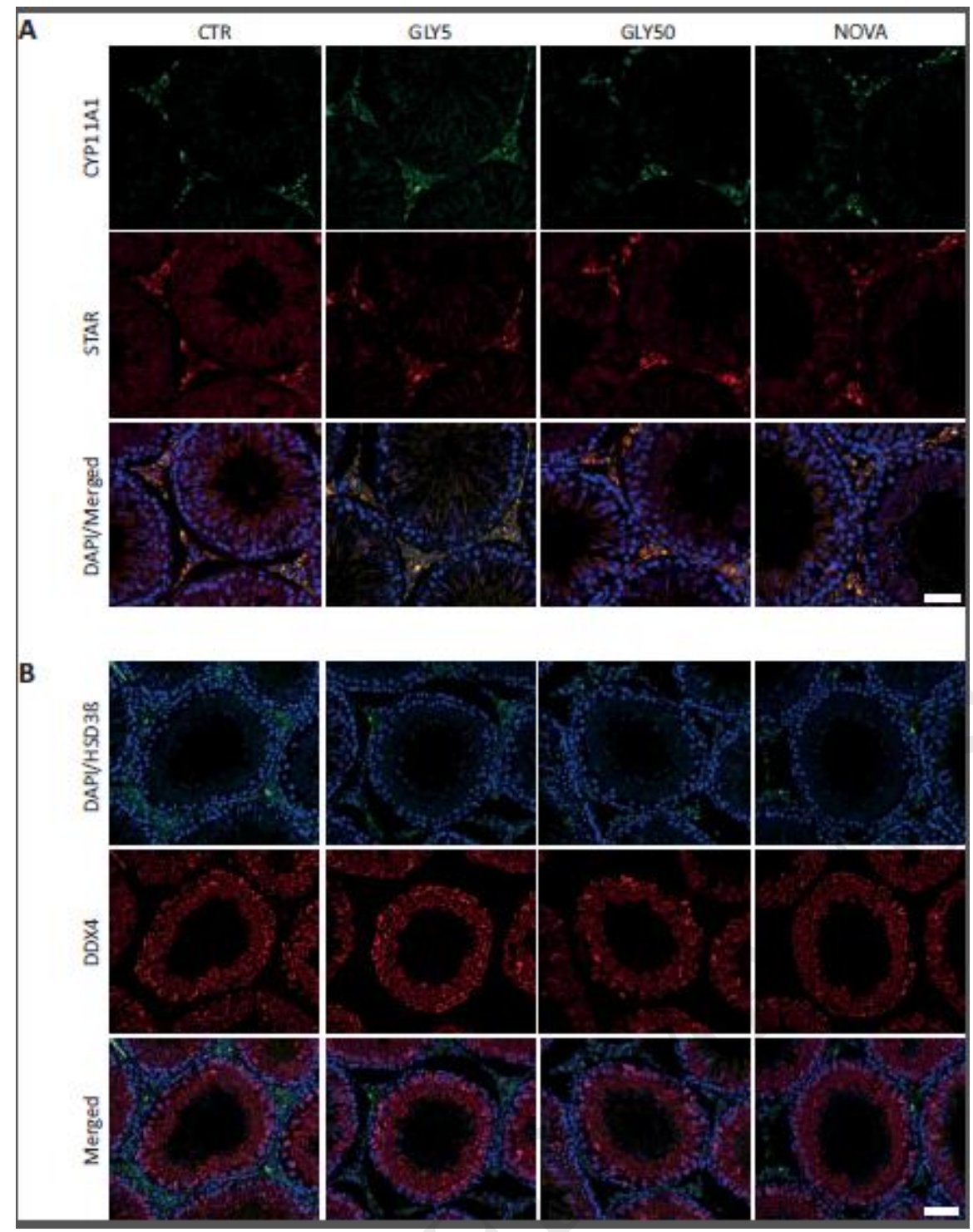




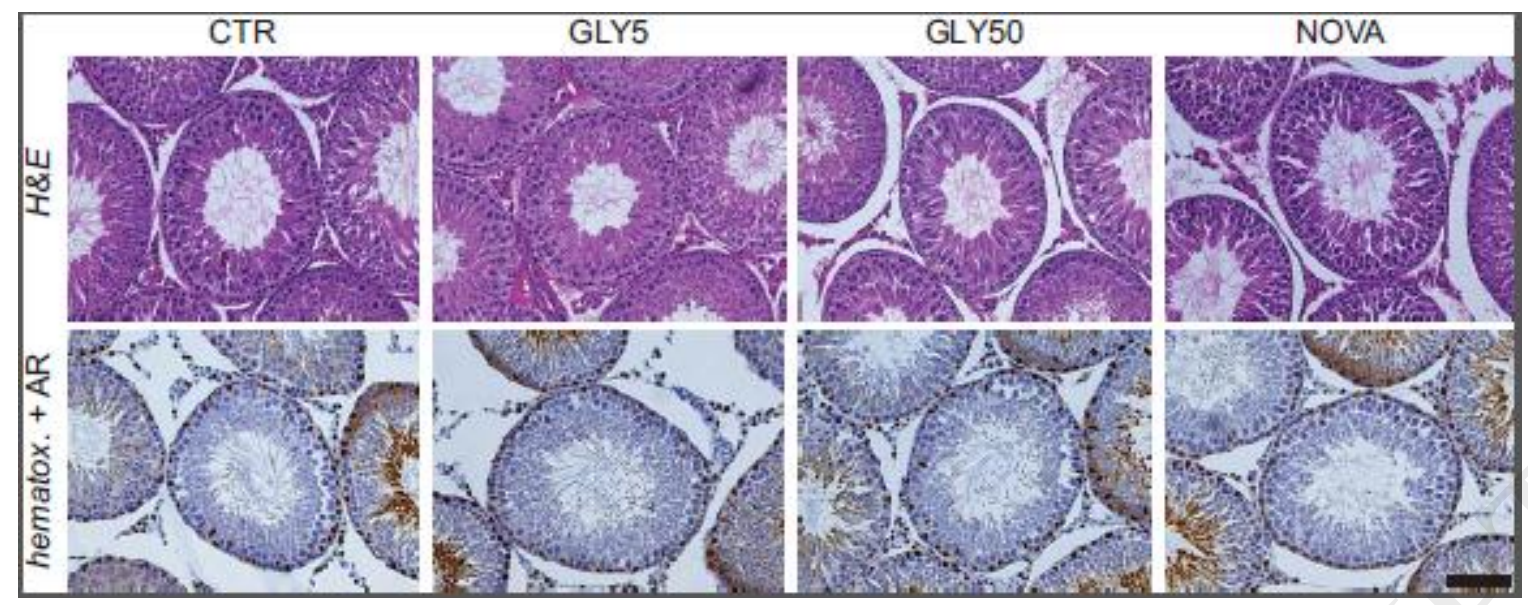




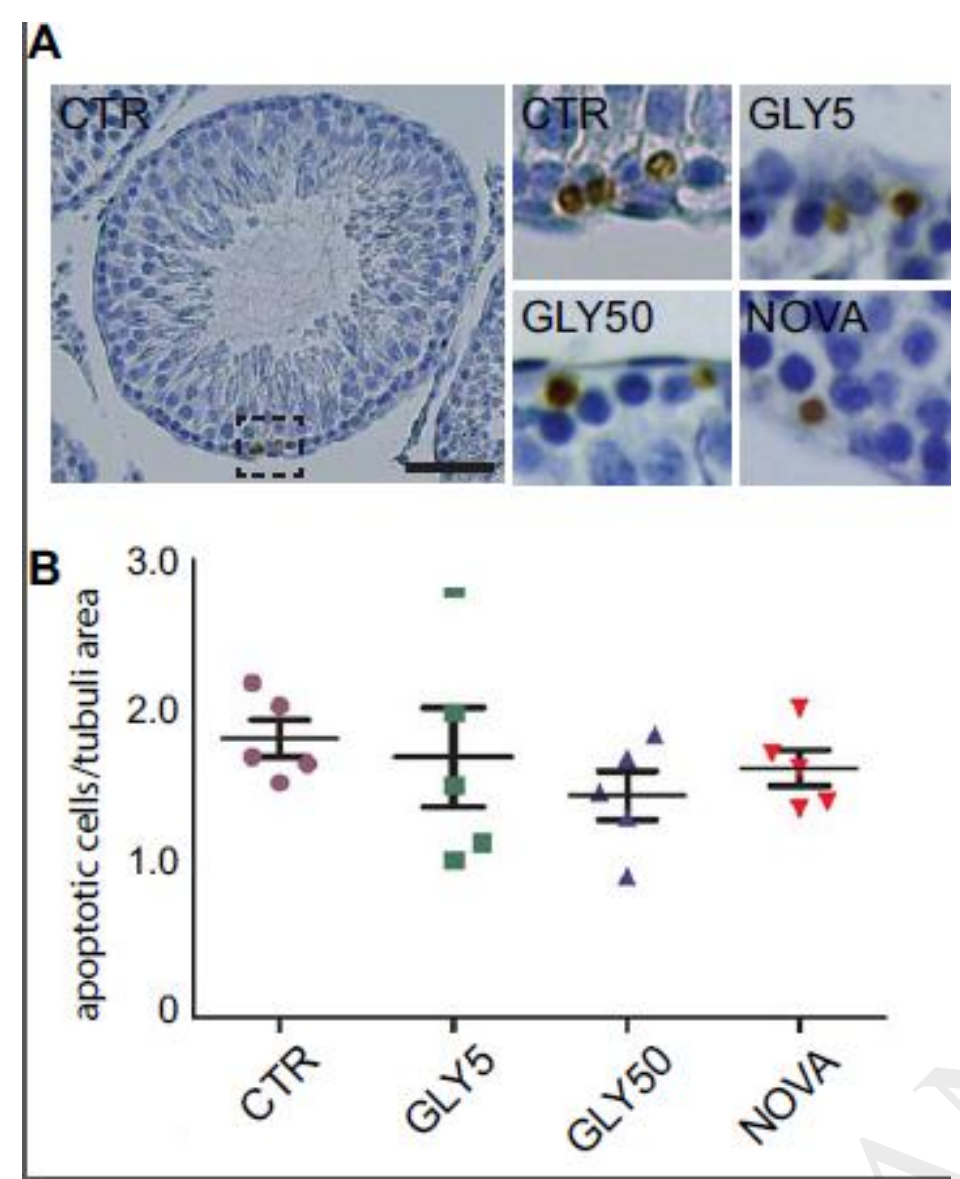

